\title{
Physiological Studies on the Interactive Effects of Lead and Antioxidants on Carum carvi Plant
}

\author{
R. M. Ali, M. H. Mahmoud, H. M. Abbas" and Marwa Fakhr \\ Botany Department, Faculty of Science,Fayoum University, Fayoum, Egypt.
}

\begin{abstract}
N EXPERIMENT was conducted to assess the responses of Carum carvi to Alead stress and using ascorbic acid and $\alpha$ tochopherol as antioxidants. In this experiment, plants were grown in the nutrient medium with different levels of lead $(0,50,100,200,500$ and $1000 \mathrm{mM})$ in the form of lead nitrate $\mathrm{Pb}\left(\mathrm{NO}_{3}\right)_{2}$. Ascorbic acid or $\alpha$ tochopherol level (each $50 \mathrm{ppm}$ ) was used as seed presoaked for $8 \mathrm{~h}$. The interactiveeffects were recorded on plant biomass, biosynthesis of photosynthetic pigments, proline, oil contents and flavonidsin Carum carvi plant. From our present results, itcouldbe concluded thatseed presoaked applications of ascorbic acid or tocopherol could play a role to alleviate the harmful effect of lead stress on some metabolic and physiological processes of Carum carvi that reflected in, increasing fresh-dry matter of different organs, inducing a significant stimulatory effect of carotenoid contents, increasing oil, proline and flavonoid contents.
\end{abstract}

Keywords: Carum carvi, $\mathrm{Pb}\left(\mathrm{NO}_{3}\right)_{2}$, Antioxidants (ascorbic acid , $\alpha$ tochopherol), Proline, Oil , Flavonoids.

\section{Introduction}

Heavy metal pollution has become a global environmental threat. Among metal contaminants, lead $(\mathrm{Pb})$ is a major concern because of its extensive distribution in the environment and the substantial environmental and human health problems it can cause (Dey \& Mondal, 2016).

While plants need many metals such as iron, magnesium, copper, or zinc, other metals such as lead or cadmium are highly toxic(Horbowicz et al., 2013). Although lead is not an essential element for plants, it is absorbed easily and accumulated in different plant parts (Sharma \& Dubey, 2005). It exerts adverse effect on plant growth(Hadi et al., 2010), changes in chemical composition, antioxidant enzymes system(Gupta et al., 2009, 2010) and lower uptake of many minerals. Lead can cause various physiological and biochemical dysfunctions of many physiological and biochemical processes such as nitrogen assimilation and photosynthesis, (Sharma \& Dubey, 2005 and Seregin \& Kosevnikova, 2008 ). Also lead, induces oxidative stress by producing reactive oxygen species which in turn causes damage to various biomolecules like membrane lipids, proteins, chloroplast pigments, enzymes, nucleic acids, etc. (Sharma \& Dubey, 2005).

Researches on certain medicinal and aromatic plants showed that they can be more resistant to some heavy metals and other pollutants than other crops (Bağdat \& Eid, 2007). Aromatic plants also have a demonstrated ability to accumulate heavy metals (Zheljazkov et al., 2006 and LydakisSimantiris et al., 2016).

Some reports demonstrated that, with planting variety of medicinal plants such as Basli, Peppermint and Anet (Dill), instead of crops in area contaminated by heavy metals like lead, copper and cadmium, although, plant's growth decreased, but there is no change oil content and without significant yield reduction (Zheljazkov et al., 2006). They suggest possible use of aromatic plants as heavy metal accumulatorsfor cleansing contaminated sites (Lydakis-Simantiris et al., 2016).

\#Corresponding aurhor email: heshammb57@yahoo.co.uk 
Plants possess a sophisticated and interrelated network of defense strategies to avoid or tolerate heavy metal toxicities (Emamverdian et al., 2015). The first defense strategy is to avoid the metal entry into the cell excluding it or binding it to a cell wall (Mishra et al., 2006 and Zhou et al., 2010). The second defense systems, once heavy metal ions enter tissues and cells, plants initiate several cellular defense mechanisms constitute various antioxidants to nullify and attenuate the adverse effects of heavy metals(Reddy et al., 2005 and Wang et al., 2010).

To mitigate the harmful effects of free radicals, plant cells have developed antioxidant defense mechanism which is composed of enzymatic antioxidants and nonenzymatic antioxidants like ascorbate (AsA), glutathione (GSH), carotenoids, $\alpha$-tocopherols, proline, and phenolic compounds (as flavonoids) that act as scavengers of free radicals (Michalak, 2006 and Sharma et al., 2012).

Antioxidants have synergistic effects on growth, yield and yield quality of many plant species. These compounds have beneficial effects on catching the free radicals or the active oxygen produced during photosynthesis and respiration processes (Foyer et al., 1991 and Al Qubaie, 2012).

Ascorbic acid (vitamin C) is one of the most important water soluble antioxidants in plants, having an essential role in several physiological processes, including plant growth, differentiation, and metabolism (Atharetal., 2008). It is acting as a modulator of plant development through hormone signaling and as coenzyme in reactions by which carbohydrates, fats and proteins are metabolized (Postori et al., 2003 and Nahed et al., 2009). Ascorbic acid is involved in the regulation of many critical biological processes such as photoinhibition and cell elongation (Noctor et al.,1998) and many other important enzymatic and non enzymatic reactions (Smirnoff, 2000). Moreover, ascorbic acid is very important for the regulation of photosynthesis, flowering and senescence (Barth et al., 2006), as well as for $\alpha$-tocopherol regeneration, which has been reported to act as the primary antioxidant (Bortoli et al., 1997).

Ascorbate can directly scavenge oxygen free radicals with and without enzyme catalysts by recycling tocopherol to the reduced form. Ascorbate can reactwith activated oxygen more readily than any other aqueous component, and protects critical macromolecules from oxidative damage (Foyer, 1993).
$\alpha$-Tocopherol (vitamin E) is a small lipophilic antioxidant that is synthesized in all higher plants (Fryer, 1992 and Bafeel \& Ibrahim, 2008). Its levelvaries in different tissues and fluctuate during development and in response to abiotic stresses. It interacts with the polyunsaturated acyl groups of lipids, stabilizes membranes, scavenges and quenches various ROS (Maeda \& DellaPenna, 2007) thus protects polyunsaturated fatty acids from lipid peroxidation and modulates signal transduction (Noctor, 2006).

In cooperation with the xanthophylls cycle, vitamin $\mathrm{E}$ fulfills at least two different functions in chloroplasts at the two major sites of singlet oxygen production: it preserves PSII from photoinactivation and protects membrane lipids from photooxidation (Havaux et al., 2005). Plants pre-treated with $\alpha$-tocopherol showed induced stress tolerance and protection against oxidative damage due to various stresses (Kumar et al.,2012).

Proline is known to occur in many plant species and normally accumulates in large quantities in responses to metal toxicity (Tripathi \& Gaur, 2004), It is noted that prolineis a good indicator stress and it has an important role in osmotic adjustment. It contributes to the stability of the sub cellular structures by scavenging free radicals under stress conditions (Ashraf \&Foolad, 2007 and Molinari et al., 2007).

Regarding oil content, Tarraf et al. (1999) stated that ascorbic acid treatment caused pronounced increase in lemongrass essential oil percent and oil yield per plant(Gamal El-Din, 2005 and Ayad et al., 2009).

Flavonoids are secondary plant metabolites with a vast array of possible functions, including antioxidative activity and as chelators for metals (Michalak, 2006; Keilig \& Ludwig-Müller, 2009a and Ilboudo, et al., 2012). The functional diversity of flavonoids is due to their structural diversity. This diversity endows flavonoids with many biological functions in addition to their role as antioxidants in the plant (Tahara, 2007 and Symonowicz \& Kolanek, 2012)

This investigation aimed to assess the efficiency of two antioxidant vitamins (ascorbic acid and $\alpha$ tocopherol) in alleviating lead stress on Carum carvi plant through their actions on fresh and dry wt., photosynthetic pigments,proline, oil contents and as well as flavonoids. 


\section{Materials and Methods}

The plant material used in this investigation was Caraway "Carum carvi" family apiaceaeas important medicinal plant grown in sand area in Egypt. Seed were kindly supplied by the Egyptain Ministry of Agriculture. seeds of the plant were selected for uniformity of size, shape, and viability. Before sowing, the seeds were surface sterilized by soaking for $2 \mathrm{~min}$ in $0.1 \%$ mercuric chloride, after which they were washed several times with distilled water. 10 healthy seeds were sown in pot $30 \mathrm{~cm}$ in diameter filled with $10 \mathrm{~kg}$ air dry soil [(clay/sand 1:2) v/v]. The seeds of tested plant were divided into three groups. The first group was treated with different concentration of $\mathrm{Pb}\left(\mathrm{NO}_{3}\right)_{2}(0.0,50,100,200,500,1000 \mathrm{mM})$. And the second group, the seeds were presoaked in 50 p.p.m ascorbic acid for $8 \mathrm{~h}$ before sowing them (based on preliminary studies), then treated with different concentration of $\mathrm{Pb}\left(\mathrm{NO}_{3}\right)_{2}$ solution $(0.0,50,100,200,500,1000 \mathrm{mM})$. Whereas the third group, seeds were presoaked in 50 p.p.m $\alpha-$ tocopherol acetate for $8 \mathrm{~h}$, then treated with different concentration of $\mathrm{Pb}\left(\mathrm{NO}_{3}\right)_{2}(0.0,50,100$, 200, 500, $1000 \mathrm{mM}$ ).

The plants were grown in a greenhouse, irrigation was carried at intervals during the experiment with sufficient tap water with $100 \mathrm{~mL}$ of Hogland's solution (Hewitt, 1966) to keep the soil content at field capacity. In order to prevent the accumulation of pollutants, the soil in each pot was leached every ten days with excessive amount of distilled water.

Three replicates were used for each set of experiment. Fresh and dry matter of the different organs (roots, shoots and flowers) were determined at the end of experiments (after 60 days).

\section{Determination of photosynthetic pigments}

Plants were harvested two times after exposure to lead heavy metal (30, 60 days),then The photosynthetic pigments (chlorophyll a, $\mathrm{b}$, and caroteniods) were determined using the spectrophotometric method recommended by (Metzner et al., 1965) and applied for higher plants (Ahmed et al., 1980 ).

\section{Determination of free proline}

Free proline was determined according to (Bates et al., 1973).Approximately $50 \mathrm{mg}$ of dry plant material was homogenized in $10 \mathrm{ml}$ of $3 \%$ aqueous sulfosalicylic acid and the homogenate was filtered through Whatman filter paper.
Two $\mathrm{ml}$ of the filterate was reacted with $2 \mathrm{ml}$ acidninhydrin reagent and $2 \mathrm{ml}$ of glacial acetic acid for 1 hat $100{ }^{\circ} \mathrm{C}$.After cooling the coloured reaction product was extracted with 4 mltoluene. Shaken vigorously with a test stirrer for 15-20 sec. The chromophore layer containing toluene was separated from aqueous phase, warmed to room temperature. The absorbency was determined from standard curve and calculated as mg proline/ gm dry matter.

\section{Determination of oil content}

The method adopted for extraction of oil (the content of an oleaginous material) was that described by Meara (1955) and applied by Younis et al. (1987).

\section{Determination of flavonoids content}

Flavoniods of the plant material were extracted with $80 \%$ methanol at $60{ }^{\circ} \mathrm{C}$, shaken for $20 \mathrm{~min}$, and filtered. The filtrate was diluted at 1:3 and $100 \mu 1$ of reactive solution (1\% 2-amino-ethyle diphenyl borate) was added (Hariri et al., 1991) and spectrophotometric measurements were done at wavelength of $404 \mathrm{~nm}$. Extract absorption was compared with that of standard (Luteolin) resulting in the calculation of total amount of flavonoids.

\section{Statistical analyses}

The experimental design was a random complete block, with three replications. The data were analyzed by the STATGRAPHICS (Statistical Graphics Corporation, Princeton USA) statistical package by the t-test and ANOVA functions to assess significant differences a many means.

\section{Results}

Growth of Carum carvi plants in Table 1 reaveled that fresh -dry matter of both roots and shoots origenating from seeds ( none soaked with antioxidants, ascorbic or $\alpha$-tocopherol acetate) were increased with the rising of $\mathrm{Pb}$ level when compared with the control. Whereas, the fresh and dry matter of flowers decreased with increasing the concentration of $\mathrm{Pb}$ levels. Also, the results indicated that plants originated from seeds soaked in ascorbic acid or $\alpha$-tocopherolonly, led to highly significant increased in both fresh and dry matter of different organs.

Plants origenated from seeds presoked in ascorbic acid, and treated with different concentrations of $\mathrm{Pb}$ increased fresh and dry matter of shoot in respect to the control but 


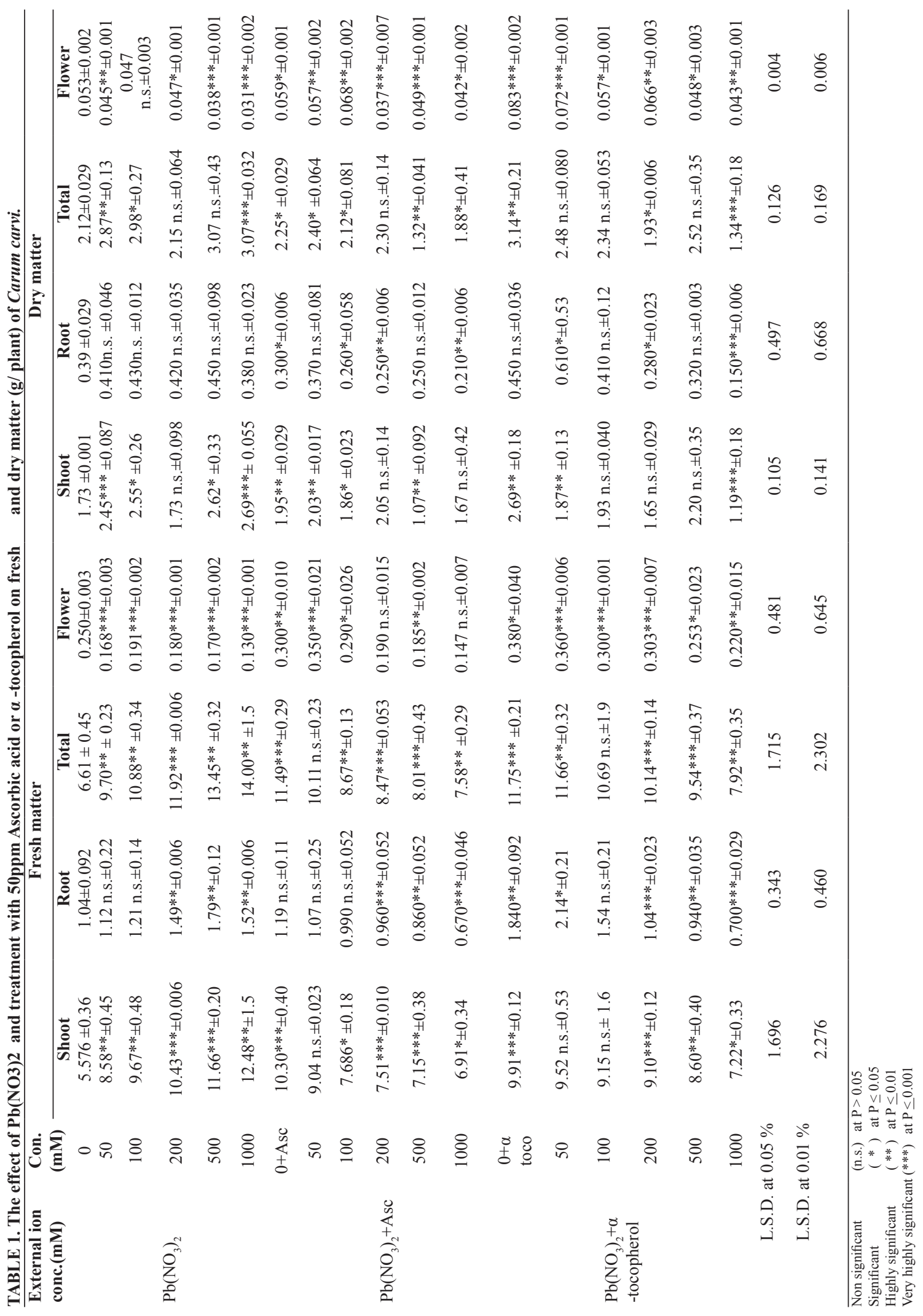

Egypt. J.Bot. 57, №.2 (2017) 
decreased the fresh and dry weight of both shoot and roots with increasing the cocentrations of $\mathrm{Pb}$. Where as the fresh and dry matter of the flowers increased at lower concentrations of $\mathrm{Pb}$ (up to $100 \mathrm{mM}$ ). However, plants origenated from seeds presoked in $\alpha$-tocopherol and treated with different concentrations of $\mathrm{Pb}$ concentrations were increased fresh and dry matter of shoot and flowers with increasing the cocentrations of $\mathrm{Pb}$ but in roots increased up to $100 \mathrm{mM}$ of $\mathrm{pb}$.

Photosynthetic activity (Tables 2 and 3 ) is one of the highly sensitive responses of stress in plants. And most of the heavy metals are known to inhibit this process to varying levels. The biosynthesis of $\mathrm{Chl} \mathrm{a,} \mathrm{Chl} \mathrm{b}$ as well as total pigments in Carum carvi leaves decreased gradually with increasing the levels of $\mathrm{Pb}$ ions at 30 and 60 days. But, at 60 days, the content of $\mathrm{Chl} b$ in plants treated with $\mathrm{Pb}$ increased with increasing metal levels up to 200 $\mathrm{mM}$ above that decreased. In case of Carum carvi plants originated from seeds soaked in ascorbic acid and treated with different levels of $\mathrm{Pb}$ at 30

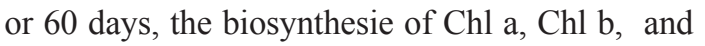
carotenoids decreased the values of Chl a and $\mathrm{Chl} \mathrm{b}$, while the carotenoid at 30 days increased up to $200 \mathrm{mM}$ when compared with corresponding levels of lead metal. In case of plants treated with $\alpha$ tocopherol, the photosynsetic pigments increased with increasing the concentrations of $\mathrm{pb}$ to $100 \mathrm{mM}$ above that decreased while at 60 days the value of $\mathrm{Chl}$ a and $\mathrm{Chl} \mathrm{b}$ increased up to 500 and $200 \mathrm{mM}$ of lead metal.

Seed-presoaked applications with either ascorbic acid or $\alpha$-tocopherol acetate not only alleviated the inhibitory effect of $\mathrm{Pb}$ on the biosynthesis of photosynthetic pigments but also induced a significant stimulatory effect.

Proline content, which is a significant stress indicator, increases in the different organs of test plant, with increasing treatment concentrations of lead (Table 4). Proline content in the plants originated from treated seeds with ascorbic acid showed increment pattern in shoots of Carum carvi significantly, but decreased in roots. Also increase in proline content was observed along with increasing lead concentrations at $50 \mathrm{mM}$ in roots and up to $500 \mathrm{mM}$ in shoot above that decreased. However, the plants originated from seeds soaked in $\alpha$ - tocopherol significantly increased proline content in both roots and shoots of plants. Whereas, the proline content in roots and shoots of these plants treated with pb increased up to $100 \mathrm{mM}$ above that decreased.

Table 5 shows clearly that the trend of oil contents of Carum carvi roots, shoots and flowers were considerably increase with rising of $\mathrm{pb}$ levels up to $200 \mathrm{mM}$ above that decreased. It was observed that ascorbic acid and $\alpha$-tocopherol application led to a significantly increasing in oil contents in different organs of Carum carvi plants especially at $\alpha$-tocopherol treatments. Oil contents, in plants originated from seeds soaked in ascorbic acid were increased with rising pb levels in roots up to $200 \mathrm{mM}$, while shoots and flowers up to 500 $\mathrm{mM}$, above these two concentrations, oil contents was decreased. Also, the soaked application in $\alpha$ tocopherol in Carum carvi plants then treated with $\mathrm{Pb}$ levels increased in oil contents in roots, flowers up to $200 \mathrm{mMand}$ in shoots at all levels. Generally, soaked application in ascorbic acid or $\alpha$-tocopherol and treated with $\mathrm{Pb}$ metal ions increased the oil content in different organs of organs of plants when compared with the corresponding treatments with $\mathrm{Pb}$.

The flavonoids contents (Table 6) increased non-significantly with the rising of the pb levels up to $200 \mathrm{mM}$ in roots, $50 \mathrm{mM}$ in shoots and 100 $\mathrm{mM}$ in the flowers and above these levels these values decreased. The plants originated from seeds soaked in ascorbic acid or $\alpha$-tocopherol showed an increase in their flavonoids contents when compared with control in different organs in tested plants. However, Carum carvi plants originated from seeds soaked in ascorbic acid or $\alpha$-tocopherol and treated with pb exhibited increased in flavonoid contents in roots, shoots and flowers up to $200 \mathrm{mM}$.

\section{Discussion}

The accumulation of fresh-dry matter of roots and shoots of Carum carvi was mostly enhanced with increasing metal levels $(\mathrm{Pb})$. This indicates that Carum carvi has an ability to exhibit variable responseto heavy metal $(\mathrm{Pb})$ stress. The same conclusion was recorded by Zheljazkove et al. (2006). In contrast, the value of fresh-dry matter of flowers generally decreased with increasing the heavy metals stress $(\mathrm{Pb})$. The same conclusion was recorded by Chauhan et al. (2004).

The inhibitory effect of heavy metals stress induced by $\mathrm{Pb}$ growth parameters of Carum carvi is in agreement with the results obtained by some authors using different plants (Chatterjee et al., 2004; Mishra et al., 2006; Sharma \& Dubey, 2005; Hadi et al., 2010; Zhou et al., 2010 and Gupta et

Egypt. J.Bot. 57, No.2 (2017) 


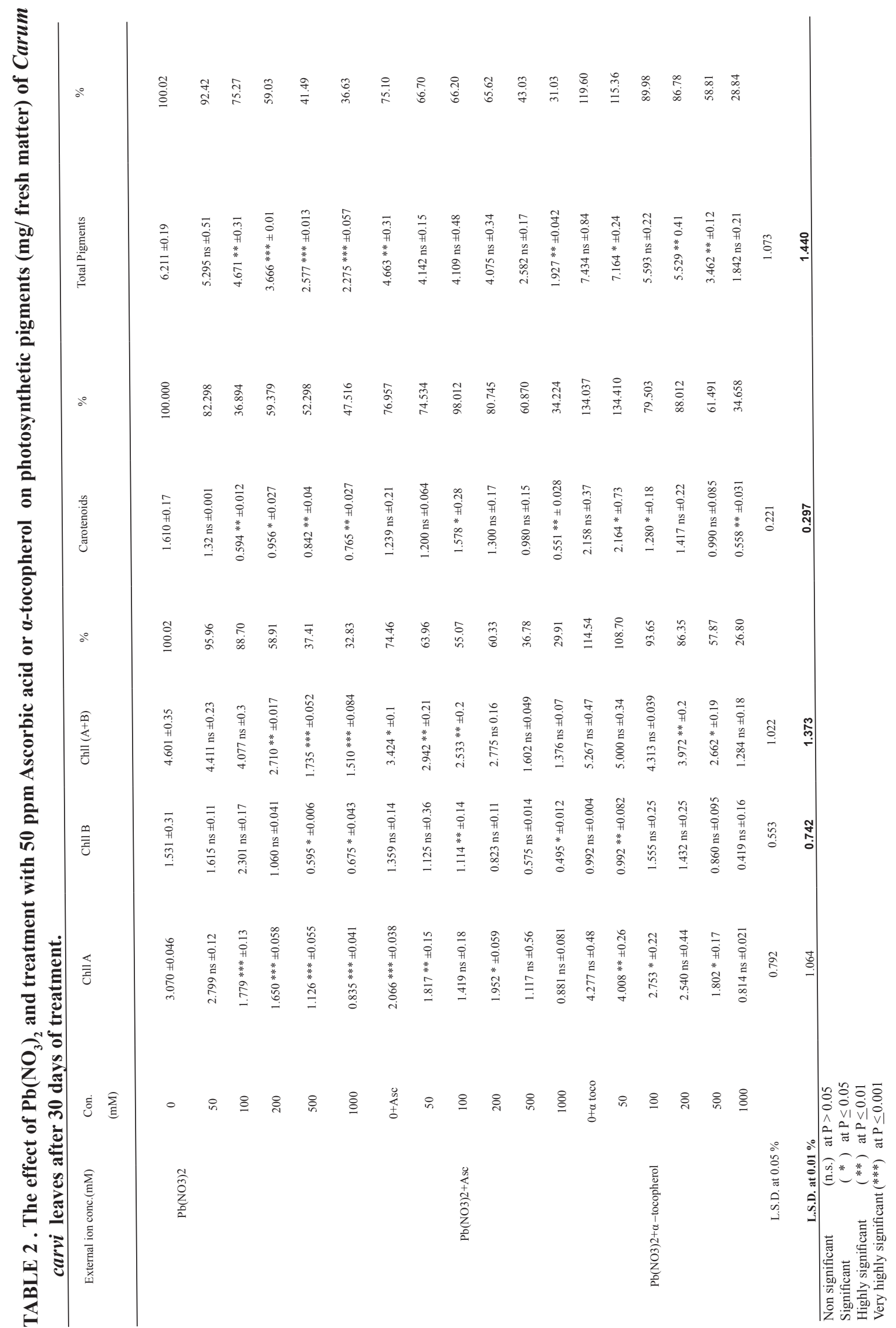

Egypt. J.Bot. 57, No.2 (2017) 


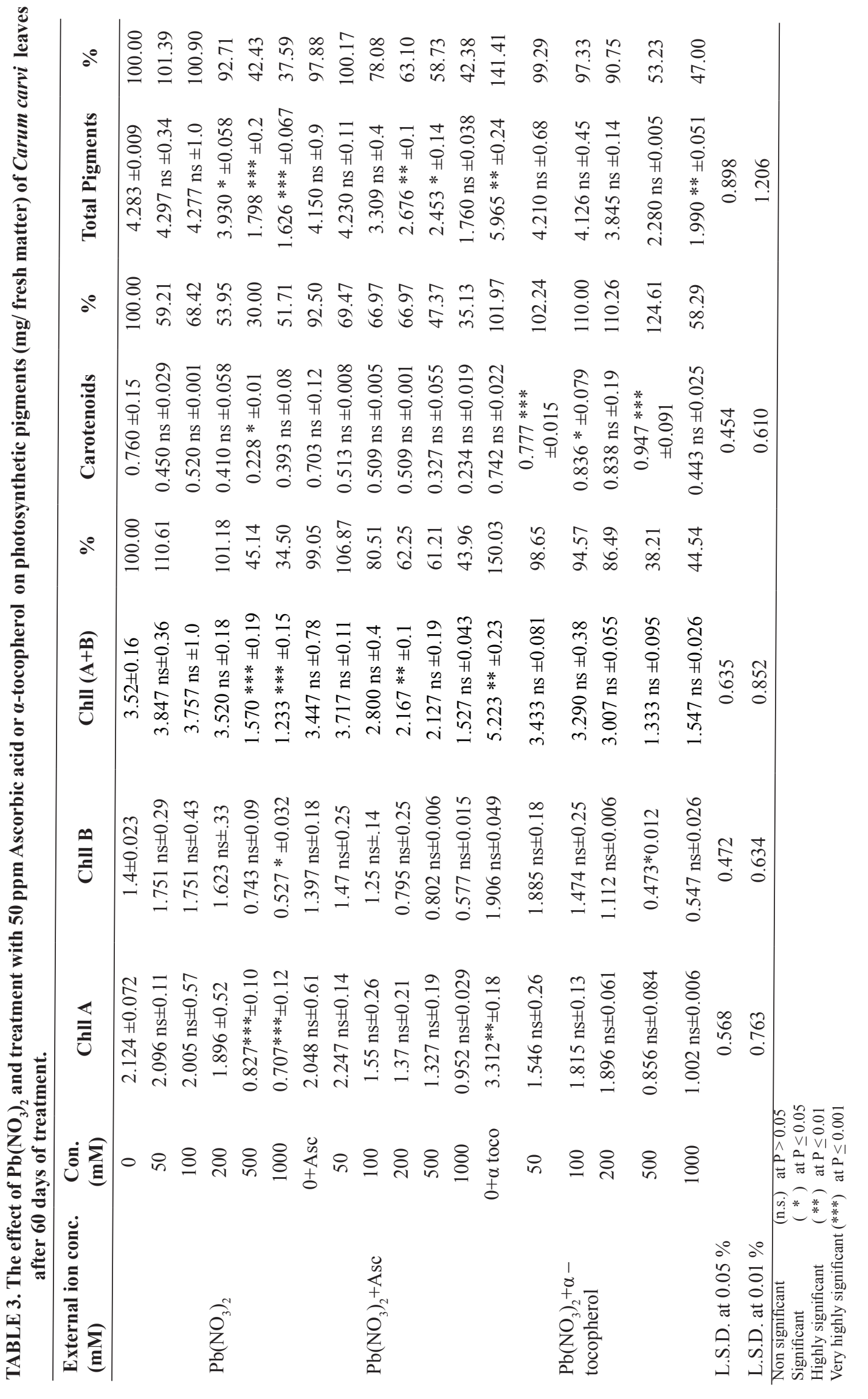

Egypt. J.Bot. 57, No.2 (2017) 


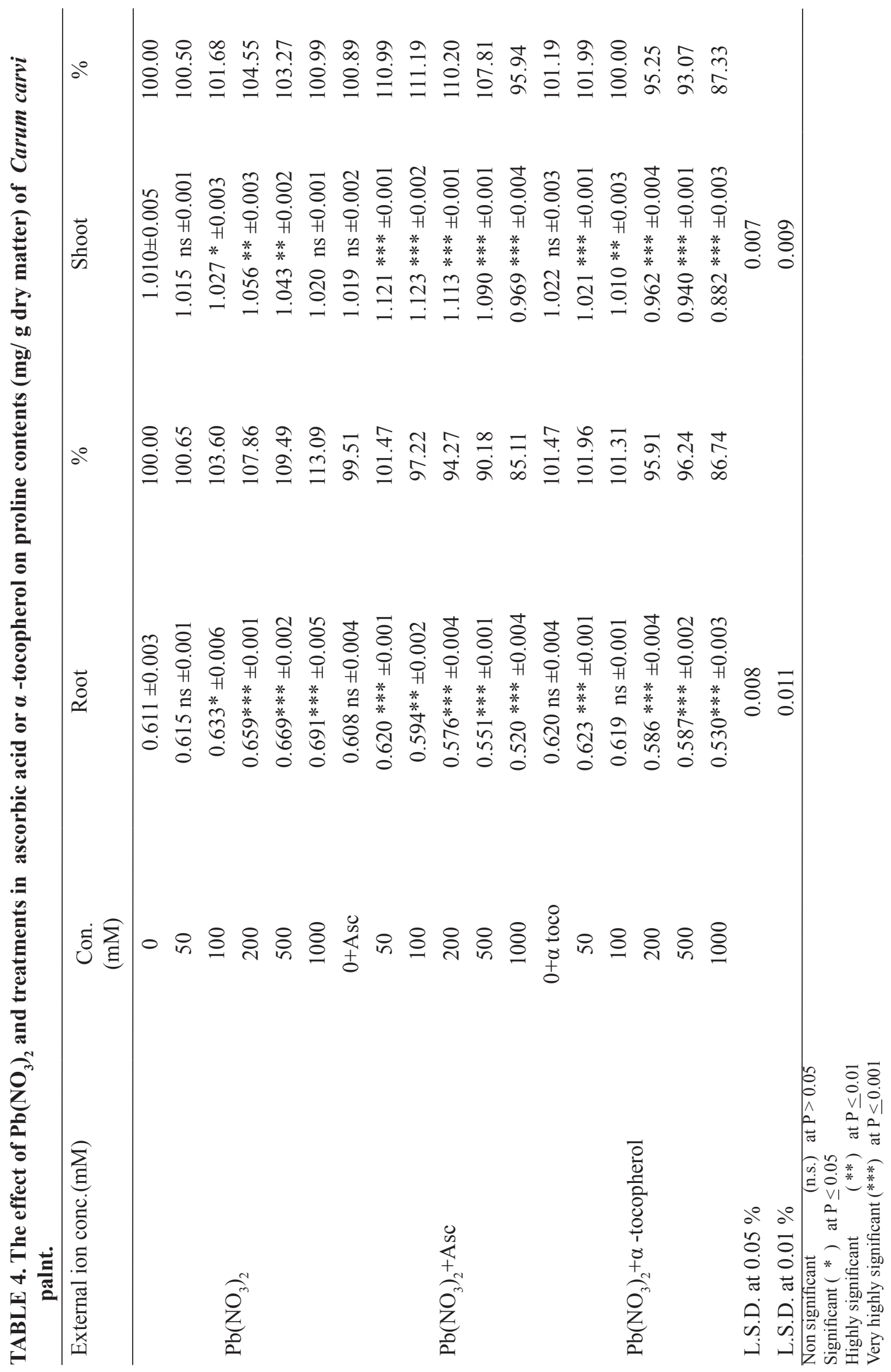

Egypt. J.Bot. 57, No.2 (2017) 


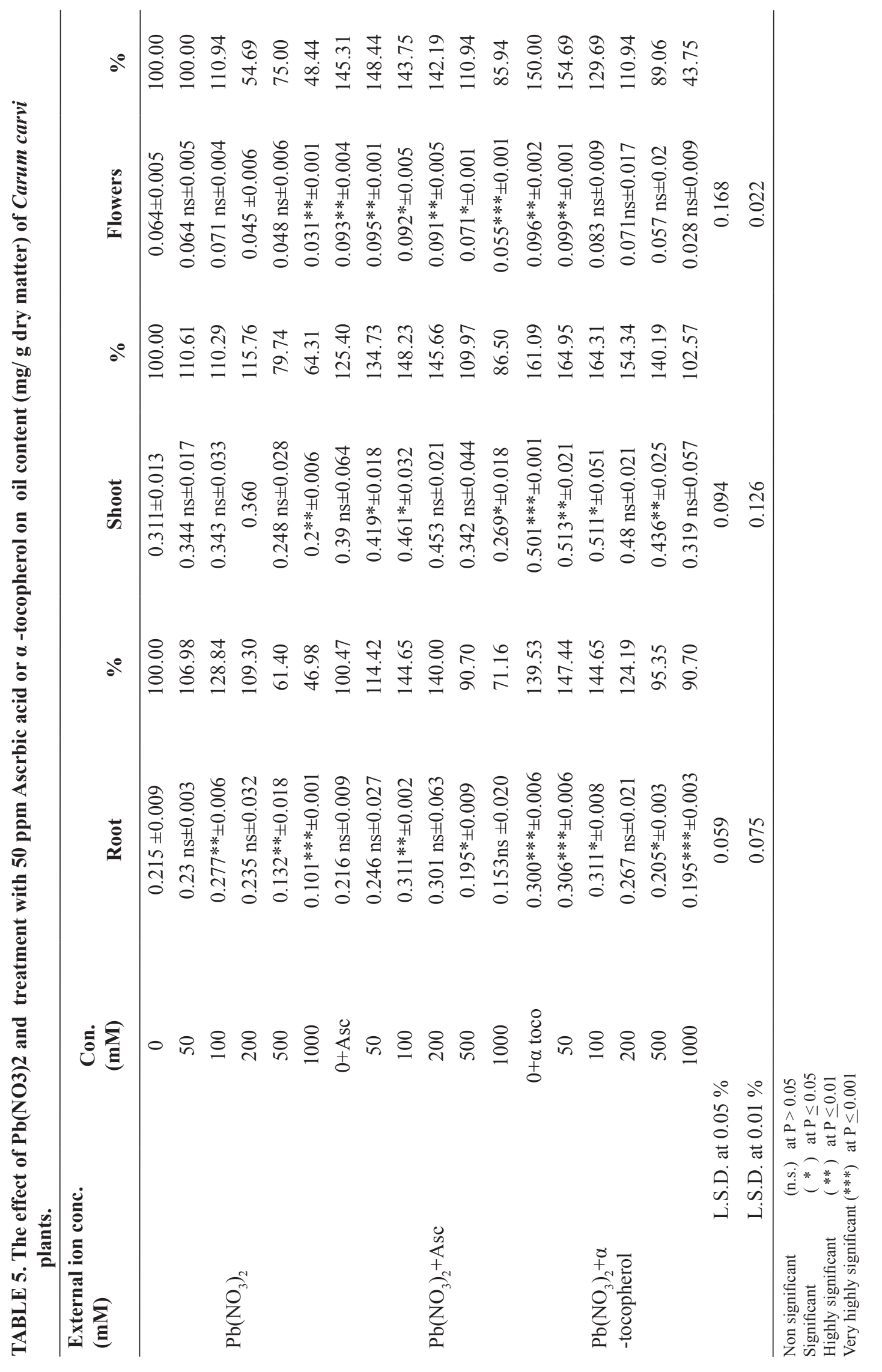

Egypt. J.Bot. 57, No.2 (2017) 


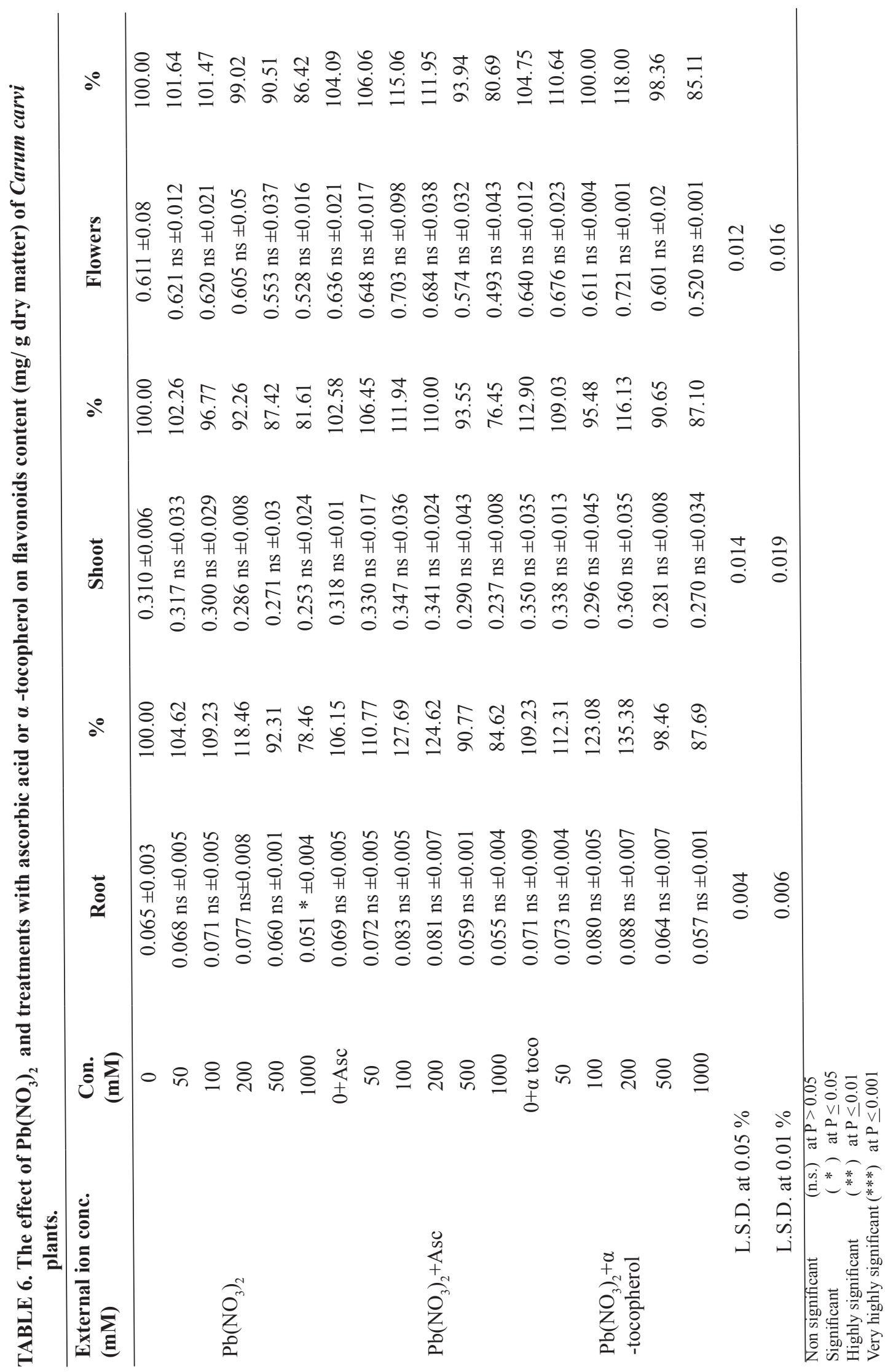

Egypt. J.Bot. 57, No.2 (2017) 
al. 2016).

Soaking the seeds in ascorbic acid or $\alpha$ tocopherol solutions significantly increased fresh-dry matter of different organs of Carum carvi plants. Ascorbate has been shown to have an essential role in several physiological processes in plants, including growth, differentiation and metabolism (Foyer, 1993 and Gamal El-Din, 2005). Ascorbic acid is cofactors for enzyme activity, and effects on plant antioxidation capacity, heavy metal evacuation and detoxification and stress defense (Zhang, 2012). Also, the same conclusion by El-Quesni et al., (2009)who mentioned that application of $\alpha$-tocopherol increased fresh weight of shoots and roots in Hibiscus rosasineses L. plants. The antioxidant properties of $\alpha$-tocopherol are the result of its ability to quench both singlet oxygen and peroxides (Fryer, 1992). Ascorbic acid plays an important role in $\alpha$-tocopherol regeneration which has been reported to act as the primary antioxidant (Bortoli et al., 1997).

Soaking application of ascorbic acid or $\alpha$-tocopherol together with $\mathrm{Pb}$ effectively increased the fresh-dry matter of shoots in Carum carvi plants. In contrast, the values of fresh-dry matter of roots and flowers generally decreased with increasing $\mathrm{Pb}$ except under 50 and $100 \mathrm{mM}$ of $\mathrm{Pb}$ were increased.These results are consistent with the studies of Foyer, (1993) who reported that exogenous application of ascorbic acid or $\alpha$-tocopherol can overcome the harmful effect of heavy metal stress.

The inhibitory effect of heavy metal on the pigment biosynthesis, in the present investigation, is in agreement with the results obtained by some other authors (Chatterjee et al., 2004; Odjegba \& Fasidi, 2006; Liu et al., 2008; Singh et al., 2010; Cenkci et al., 2010 and Rossato et al., 2012). Pb has reduced the photosynthetic pigments (chlorophyll a and b) significantly because $\mathrm{Pb}$ prevents the incorporation of $\mathrm{Fe}$ (iron) in phytoporphyrin ring of chlorophyll molecule, so cause reduction in chlorophyll contents (Jaleel et al., 2009 and Kumar et al. 2012) and also, may be attributed to increase in activity of chlorophyll-degrading enzyme chlorophyllase under stress conditions (Liu et al., 2008).

The decrease in photosynthesis might be due to striking change in fine structure of chloroplasts (Sadak \& Dawood 2014) and also due to destruction of marginal membranes of meristematic cells when $\mathrm{Pb}$ is present at high concentrations. Also, the inductions of oxidative stress by heavy metals might be due to blockage of electron flow in photosystem II (Kato \& Shimizu, 1987).

Dela Rosa-Ibarra \& Maiti (1995) assumed that the tendency to decrease in the chlorophyll content might be due to the synthesis of nitrogen compounds acting as osmotic regulators e.g proline consumes a large amount of nitrogen. These observation are in good agreement with our present results of Carum carvi plants which showed that the decrease in the biosynthesis of photosynthetic pigments under heavy metal stress $(\mathrm{Pb})$ was accompanied by an increase in the biosynthesis of nitrogen compounds (proline).

The content of carotenoid when treated with $\mathrm{Pb}$ at 30 days their pigments increased up to $200 \mathrm{mM}$ above that decreased. In terms of its antioxidant properties carotenoids can protect the photosystems is one of four ways by reacting with lipid peroxidation products to terminate chain reactions (Burton \& Ingold, 1984), by scavenging singlet oxygen and dissipating the energy as heat by reacting with triplet or excited chlorophyll molecules to prevent formation of singlet oxygen or by the dissipation of excess excitation energy through xanthophylls cycle (Havaux et al., 2005).The inhibitory effect of heavy metals stress on the carotenoids is in agreement with the results obtained by Chatterjee et al. (2004).

After 30 or 60 days the content of $\mathrm{Chl}$ a and $\mathrm{Chl} \mathrm{b}$ of heavy metals $(\mathrm{Pb})$ Carum carvi, plants treated with ascorbic acid were decreased, while $\alpha$-tocopherol increased up to $100 \mathrm{mM}$ of $\mathrm{Pb}$ above that decreased. Ascorbic acid may be have some phytotoxic effect on chlorophyll function. In other word, decreased chlorophyll content (Kiani et al., 2008). The enhancement roles of $\alpha$ tocopherol on photosynthetic pigments are in agreement with those reported by Kumar et al. (2012) on stressed wheat and Al Qubaie (2012) on sunflower, since, $\alpha$ tocopherol may be protected the organization of the chloroplast thus minimize chlorophyll loss.

Generally carotenoid contents in Carum carvi plants increased under moderate level of $\mathrm{Pb}$ when treated with ascorbic acid or $\alpha$-tocopherol. The increasing in carotenoids may be a strategy adopted by plants to alleviate the toxic effects 
of free radicals generated under heavy metal toxicity (Azooz et al., 2011).Carotenoids prevent the formation of singlet oxygen by quenching the triplet state of the chlorophyll molecules as they arise (Havaux et al., 2005).

With respect to proline biosynthesis, the different organs of Carum carvi plant promoted action of accumulation of proline with increase in metal $(\mathrm{Pb})$ levels in roots and shoots. Proline content is a significant stress indicator, thus it could be suggested that heavy metals $(\mathrm{Pb})$ tolerance of Carum carvi was manifested via the activated proline accumulation in the different organs. The accumulation of proline in response to heavy metals of many plants was also recorded by other investigators under laboratory conditions (Tripathi \& Gaur, 2004; Odjegba \& Fasid, 2006 and Dey \& Mondal, 2016).

There are different opinions regarding mechanisms by which proline alleviate metal toxicity effects within the cell. It has been shown that free proline acts as an osmoprotectant (Ashraf \& Foolad, 2007 and Molinari et al., 2007), proteinst abilizer (Sha rma \& Diez,2005), metal chelator (Sharma \& Dubey, 2005), inhibitor of lipid peroxidation (Mehta \& Gaur, 1999), free radical scavenger (Ashraf \& Foolad, 2007 and Molinari et al., 2007), prevent enzyme destruction, and decrease the toxic effects of lead (Tripathi \& Gaur, 2004). Therefore, it may be concluded that the accumulation of proline could be regarded as one of the major physiological mechanisms of heavy metals stress tolerance in the experimental plant.

However, Proline content in the different organs of test plant was induced by soaking plant seeds in ascorbic acid or $\alpha$-tocopherol. The proline content of plants whose their seeds pretreated with ascorbic acid increased significantly in shoots of Carum carvi but decreased in roots of the plants. Whereas, soaking application in $\alpha$-tocopherol increased significantly the proline content in both roots and shoots of the plants.

There is much evidence that ascorbic acid or $\alpha$-tocopherol plays an essential role in several physiological processes in plants, including growth differentiation and metabolism (Foyer, 1993). Ascorbate functions as a reductant for many free radicals, thereby minimizing the damage caused by oxidative stress. Ascorbate can directly scavenge oxygen free radicals with and without enzyme catalysts and can indirectly scavenge them by recycling $\alpha$-tocopherol to reduced form (Asada, 1992). Tocopherol is actually a family of antioxidants (Hess, 1993). The antioxidant properties of tocopherol are the results of its ablitiy to quench both singlet oxygen and peroxides (Fryer, 1992 and Maeda \& Della Penna, 2007).

A response of significance in connection with the role of soaking application of ascorbic acid or $\alpha$-tocopherol as antioxidant in modifying the heavy metal stress induced changes was also revealed in the present investigation with respect to the biosynthesis of, proline.Soaking application in ascorbic acid and treated with $\mathrm{Pb}$ ions increased the proline content at $50 \mathrm{mM}$ in roots and up to $500 \mathrm{mM}$ in shoot of Carum carvi above that decreased. However, proline content in roots and shoots of Carum carvi plants originated from soaked in $\alpha$-tocopherol and treated with $\mathrm{Pb}$ increased up to $100 \mathrm{mM}$ above that decreased. The application of ascorbic acid or $\alpha$-tocopherol mitigate to variable extent the adverse effect of lead stress on plant growth, may be due to, the enhanced proline accumulation.

According to these results, Schat et al. (1997) reported that the application excess metals, the responses of V.cespitosa and $S$. vulgaris population essentially resembled each other in that the sensitive lines of both species accumulated high proline contents but tolerant ones did not. The decreased relative proline accumulation in the tolerant ecotype could be due to a slower development of water deficit under metal stress (Schat et al., 1997).

Increasing $\mathrm{Pb}$ metal enhanced the oil contents in different organs of Carum carvi up to $200 \mathrm{mM}$ and decreased at higher levels of $\mathrm{pb}$. This is in accordance with the results obtained by Dahdoh \& Moussa (2000).

Generally soaking application in either ascorbic acid or $\alpha$-tocopherol increased the oil contents in roots, shoots and flowers of Carum carvi. These results are in agreement with the results obtained by Gamal El Din (2005) who observed that ascorbic acid significantly increased oil percentage of sunflower seeds and Also, $\alpha$-tocopherol treatments significantly increased essential oil percent and yield of 
Pelargonium graveolens L. (Ayad et al., 2009).

Soaking application in ascorbic acid and treated with $\mathrm{Pb}$ increased in oil content in roots, shoots and flowers up to 200, 100 and $500 \mathrm{mM}$, respectively. These results are also consistent with Sadak \& Dawood (2014). Contrary to the present results, Dolatabadian et al. (2010) mentioned that, the highest corn oil percentage was achieved from stressed plants while ascorbic acid treatments decreased it.

Soaking application in $\alpha$-tocopherol and treated with $\mathrm{Pb}$ increased oil content in roots and flowers of Carum carvi up to $200 \mathrm{mM}$ but in shoots at all levels used. These increases might be due to a pronounced enhancement of $\alpha$ tocopherol on synthesis and accumulation of oil (Ayad et al., 2009).

The flavonoids content in roots, shoots and flowers of Carum carvi were accumulated at lower and moderately levels of $\mathrm{Pb}(50,100$ and $200 \mathrm{mM}$ ). As a result of $\mathrm{Pb}$ stress, the enhanced content of flavonoids probably is responsible for binding of metal ions, due to the specific chemical structure, it can chelate metal ions like $\mathrm{Pb}^{2+}$ and form complexes (Ilboudo, et al., 2012 and Symonowicz \& Kolanek, 2012). In addition to direct free radical scavenging properties and form chelate formation compex, flavonoids have antioxidant activity, in the prevention of free radicals induced by $\mathrm{pb}$ which damage target biomolecules (Tahara, 2007 and Keilig \& Ludwig-Müller, 2009). Their antioxidant properties are related with hydroxyl group. (Symonowicz \& Kolanek, 2012). However, it was observed that several classes of flavonoids showed antioxidant activity towards a variety of easily oxidizable compounds, many of those play an important physiological and ecological role as they are involved in resistance to different types of stress (Ali \& Abbas, 2003 and Ali et al.,2007).

Soaking application in ascorbic acid or $\alpha$-tocopherol generally increased the level of flavonoids in different organs of test plant. Also, soaking application in ascorbic acid or $\alpha$-tocopherol in Carum carvi plant and treated with $\mathrm{Pb}$ up to $200 \mathrm{mM}$, induced some changes in flavonoids synthesis. Ascorbic acid or $\alpha$-tocopherol counter balanced the adverse effects of heavy metals $\mathrm{Pb}$ on growth and content of oil and flavonoids in Carum carvi.

It can be concluded that presoaking seeds of
Carum carvi in ascorbic acid or $\alpha$-tocopherol could be considered of great importance for counter balanced the adverse effects of heavy metals $\mathrm{Pb}$ on growth and content of oil and flavonoids. The tendency of the observed heavy metal $\mathrm{Pb}$ induced changes leads to an assumption that the medicinal plant tested in this investigation have some variable abilities not only to tolerate moderate heavy metals $\mathrm{Pb}$ but also to grow well and to produce the same amount or even more oil and flavonoids than the control plants.

\section{References}

Ahmed, A. M., Heikal, M. M. and Shaddad, M. A. (1980) Changes in Growth, photosynthesis and fat content of some oil producing plants over a range of salinity stresses. Acta Agronomica, 32, 370-375.

Ali, R. M. and Abbas, H. M. (2003) Response of salt stressed barley seedlings to phenyl urea. Plant Cell and Environment, 4, 158-162.

Ali, R. M., Abbas, H. M. and Kamal, R.K. (2007) The effects of treatment with polyamines on dry matter, oil and flavonoid contents in salinity stressed chamomile and sweet marjoram. Plant Soil Environ. 53 (12), 529-543.

Al Qubaie, A.I. (2012) Response of sunflowers cultivar Giza 102 (Helianthus annuus L) plants to spraying some antioxidants. Nature and Sci. 10, 1-6.

Ashraf, M. and Foolad, M. R. (2007) Roles of glycine betaine and proline in improving plant abiotic stress resistance. Environmental and Experimental Botany, 59, 206-216.

Asada, k.(1992) Ascorbate peroxidase- a hydrogen peroxide-scavenging enzyme in plants. Physiology Plant, 85, 235-241.

Athar, H.R., Khan, A. and Ashraf, M. (2008)Exogenously applied ascorbic acid alleviates salt-induced oxidative stress in wheat. Environ.Exp. Bot. 63, 224-231.

Ayad, H.S., Gamal El-Din, K. M. and Reda, F. (2009) Efficiency of stigmastrol and $\alpha$-tocopherol application on vegetative growth, essential oil pattern, protein and lipid peroxidation of geranium. J. Appl. Sci. Res. 5, 887-892.

Azooz, A.A., Youssef, M. M. and Al-Qamir, M.A.(2011) Comparative evaluation of zinc and lead and their synergistic effect on growth and physiological responses of Hassawai okra (Hibiscus esculentus) seedling. Am. J. Plant Physiol. 6(6), 269-282.

Baffel, S. O. and Ibrahim, M. M. (2008) Antioxidants and accumulation of $\alpha$-tocopherol induce chilling tolerance in Medicago sativa. Int. J. Agric. Biol.10(6), 593-598. 
Bağdat, R. B. and Eid, E. M. (2007) Phytoremedation behaviour of some medicinal and aromatic plants to various pollutants. Journal of Field Crops Central Research Institute (Ankara), 16(1-2), 1-10.

Barth, C., De Tullio, M. and Conklin, P.L. (2006) The role of ascorbic acid in the control of flowering time and the onset of senescence. J. Exp. Bot. 57,16571665.

Bates, L. S.,Waldren, R. P. and Teare, I. D. (1973) Rapid determination of free proline for water stress studies. Short Communication Plant and Soil, 39, 205-207.

Bortoli, C. G., Simontacchi, M., Montaldi, R. and Puntarulo, S. (1997) Oxidants and antioxidants during aging of Chrysantyemuspetals. Plant Science, 129, 157-165.

Burton, G.W. and Ingold, K.U. (1984) ß-carotene: an unusual type of lipid antioxidant. Science, 224, 569-573.

Cenkci, S., Cigerci, I. H.,Yildiz, M., Özay, C.,Bozdag, A. and Terzi, H. (2010) Lead contamination reduces chlorophyll biosynthesis and genomic template stability in Brassica rapa L. Environ Exp Bot. 67(3), 467-473.

Chatterjee, C., Dube, B. K., Sinha, P. and Srivastava, P. (2004) Detrimental effects of lead phytotoxicity on growth, yield andmetabolism of rice. Communications in Soil Science and Plant Analysis, 35 (1, 2), 255-265.

Chauhan, S. V. S., Chaurasia, A. and Rana, A. (2004) Impact of air pollution on floral morphology of Cassia siameaLamk. Journal of Environmental Biology, 25(3), 291-297.

Dahdoh, M. S. A. and Moussa, B. I. M. (2000) Zn-Co and Fe-Ni interactions and their effect on peanut and broad bean plants. Egyptian J. of Soil Sci. 40, 4, 453-467.

Dela Rosa-Ibarra, M. and Maiti, R. K. (1995) Biochemical mechanism in glossy sorghum lines for resistance to stress. Journal of Plant Physiology, 146, 515- 519.

Dey, U. and Mondal, N.K. (2016) Ultrastructural deformation of plant cell underheavy metal stress in Gram seedlings. Cogent Environmental Science, 2, 1196472 .

Dolatabadian, A., Mohammad, S.A., Sanavy, M. and Asilan.K.S. (2010) Effect of ascorbic acid foliar application on yield, yield component and several morphological traits of grain corn under water deficit stress conditions. Notulae Scientia Biologicae, 2, 45-50.

EL-Quesni, F. E., Abd EL-Aziz, N. and Maga, M. K. (2009) Some studies on the effect of ascorbic acid and $\alpha$-tocopherol on the growth and some chemical composition of Hibiscus rosasinensisL. at Nurbaria. Ozean J. Appl. Sci. 2(2),159-167.

Emamverdian, A., Ding, Y., Mokhberdoran, F. and Xie, Y.(2015) Heavy metal stress and some mechanisms of plant defense response. The Scientific World Journal, Vol. 2015, Article ID 756120, 18 pages.

Foyer, C., Lelandais, M., Edwards, E. A. and Mulineawx, P. M. (1991) The role of ascorbatein plants, interactions with photosynthesis and regulatory significance. In: "Active Oxygen Oxidative Stress and Plant Metabolism." Pell, E.J. and Steffen, K.L. (Ed.), pp. 131 - 144. Current Topics in plant physiology.Vol. 6. American Society of Plant Physiologists, Rockville, M. D.

Foyer, C. (1993) Ascorbic acid. In: "Antioxidants in Higher Plants." Alscher, R.G. and Hess, J.L. (Ed.), pp.31-58. CRC Press, Boca Raton.

Fryer, M. J. (1992) The antioxidant effects of thylakoid vitamin E ( $\alpha$-tocopherol). Plant Cell Environment, 15, 381-392.

Gamal El-Din, K.M. (2005) Physiological studies on the effect of some vitamins on growth and oil content in sunflower plant. Egypt. J. Appl. Sci. 20, 560-571.

Gupta, D. K., Nicoloso, F. T., Schetinger, M. R. C., Rossato, L. V., Pereira, L. B. and Castro G. Y. (2009) Antioxidant defense mechanism in hydroponically grown Zea mays seedlings under moderate lead stress. J. Hazard. Mater. 172, 479-484.

Gupta, D. K., Huang, H. G., Yang, X. E., Razafindrabe, B. H. N. and Inouhe, M. (2010) The detoxification of lead in Sedum alfredii $\mathrm{H}$. is not related to phytochelatins but the glutathione. J. Hazard. Mater. 177437-444.

Hadi, F., Bano, A. and Fuller, M. P. (2010) The improved phytoextraction of lead $\left(\mathrm{Pb}^{2+}\right)$ and the growth of maize (Zea mays L.): the role of plant growth regulators ( $\mathrm{GA}_{3}$ and IAA) and EDTA alone and in combinations. Chemosphere, 80, 457-462.

Gupta, D. K., Palma, J.M. and Corpas, F.J. (2016) Redox state as a central regulator of plant-cell stress response, Springer-Verlag, Germany, ISBN: 978-3-319-44080-4.

Hairi, B., Salle, G. and Andary, C. (1991) Involvement of flavonoids in the resistance of two cultivars to mistletoe (Viscum album). Protoplasma, 162, 2026.

Havaux, M., Eymery, F., Porfirova, S., Rey, P. and Dörmann, P. (2005) Vitamin E protects against photoinhibition and photooxidative stress in Arabidopsis thaliana. Plant Cell, 17, 3451-3469.

Hess, J. L. (1993) Vitamin E, $\alpha$-tocopherol. In: "Antioxidants in Higher Plants." R.G. Alscher and

Egypt. J.Bot. 57, No.2 (2017) 


\section{J.L. Hess (Ed.) CRC Press. Boca Raton, 111-134.}

Hewitt, E. J. (1966) Sand and water culture methods used in the study of plant nutrition. Technical Communication No. 22. Commonwealth Bureau of Horticulture and Plantation Crops, East Malling, Maidstone, Kent, England.

Horbowicz, M., Dębski, H., Wiczkowski, W., Szawara-Nowak, D., Koczkodaj, D., Mitrus, J. and Sytykiewicz, H. (2013) The impact of short-term exposure to $\mathrm{Pb}$ and $\mathrm{Cd}$ on flavonoid composition and seedling growth of common Buckwheat cultivars. Pol. J. Environ. Stud. 22 (6), 1723-1730.

Ilboudo, O., Tapsoba, I., Bonzi-Couibaly, Y. L. and Gerbaux, P. (2012) Targeting structural motifs of flavonoid diglycosides using collision-induced dissociation experiments on flavonoid $/ \mathrm{Pb}^{2+}$ complexes. Eur. J. Mass. Spectr. 18, 465.

Jaleel, C.A., Riadh, K.,Gopi, R., Manivannan, P., Inés, J., Al-Juburi H.J., Zhao C.X.,Shao, H.B. and Panneerselvam, R. (2009) Antioxidant defense responses: physiological plasticity in higher plants under abiotic constraints. Acta Physiologiae Plantarum, 31, 427-436.

Kato, M. and Shimizu, S. (1987) Chlorophyll metabolism in higher plants. VII. Chlorophyll degradation in senescing tobacco leaves: phenolic-dependent peroxidative degradation. Canadian Journal of Botany, 65, 729-735.

Keilig, M. and Ludwig-Müller, J. (2009) Effect of flavonoids on heavy metal tolerance in Arabidopsis thaliana seedlings. Botanical Studies, 50, 311-318.

Kiani, S. P., Maury, P., Sarrafi, A. and Grieu, P. (2008) QTL analysis of chlorophyll fluorescence parameters in sunflower (Helianthus annuusL.) under wellwatered and water-stressed conditions.Plant Science, $\mathbf{1 7 5}, 565-573$.

Kumar, S., Singh, R. and Nayyar, H. (2012) $\alpha-$ Tocopherol application modulates the response of wheat (Triticum aestivum L.) seedlings to elevated temperatures by mitigation of stress injury and enhancement of antioxidants. J. Plant Growth Regul. 32(2), 307-314.

Liu, D., Li, T., Jin, X., Yang, X., Islam, E. and Mahmood, Q. (2008) Lead induced changes in the growth and antioxidant metabolism of the lead accumulating and non-accumulating ecotypes of Sedumalfredii. $J$. Integr Plant Biol. 50(2), 129-140.

Lydakis-Simantiris, N., Fabian M. and Skoula M. (2016) Cultivation of medicinal and aromatic plants in heavy metal-contaminated soils. Global NEST Journal, 18(3), 630-642.

Maeda, H. and DellaPenna, D. (2007) Tocopherol functions in photosynthetic organisms. Curr.Opin.
Plant Biol. 10, 260-265.

Meara, M. L. (1955) Fats and other lipids; In: " Modern Methods of Plant Analysis", Paech, K. and Tracey, M.V. (Ed.).Vol. 2, pp. 317-402. Springerverlag, Berlin.

Mehta, S. K. and Gaur, J. P. (1999) Heavy metalinduced proline accumulation and its role in ameliorating metal toxicity in Chlorella vulgaris. New Phytologist, 143, 253-259.

Metzner, H., Rau, H. and Senger, H. (1965) Untersuchungen zur synchronisierbakeit einzelner-pigment. Mangel Mutanten von. Chlorella. Planta, 65, 186-194.

Michalak, A. (2006) Phenolic compounds and their antioxidant activity in plants growing under heavy metal stress. Pol. J. Environ. Stud.15, 523-530.

Mishra, S., Srivastava, S., Tripathi, R. D., Kumar, R., Seth, C. S. and Gupta, D. K. (2006) Lead detoxification by coontail (Ceratophyllum demersum L.) involves induction of phytochelatins and antioxidant system in response to its accumulation. Chemosphere, 65, 1027-1039.

Molinari, H. B. C., Marur, C. J., Daros, E., de Campos, M. K., de Carvalho, J. F. R. P., Filho, J. C. and Vieira, L. G. E. (2007) Evaluation of the stressinducible production of proline in transgenic sugarcane (Saccharums pp.): Osmotic adjustment, chlorophyll fluorescence and oxidative stress. Physiologia Plantarum, 130, 218-229.

Nahed, G. A., Lobna, T.and Soad, M. I. (2009) Some studies on effect of putresine, ascorbic acid and thiamine on growth, flowering and some chemical constituents of gladiolus plants at Nurbaria. Ozean J. Appl. Sci. 2(2), 169-179.

Noctor, G. (2006) Metabolic signaling in defense and stress: the central roles of soluble redox couples. Plant Cell Environ.29, 409-425.

Noctor, G., Arisi, A., Jouanin, L., Kunert, K. J., Rennenberg, H. andFoyer, C.H. (1998) Glutathione: biosynthesis, metabolism and relationship to stress tolerance explored in transformed plants. J. Exp. Bot. 49, 623-647.

Odjegba, V. J. and Fasidi, I. O. (2006) Effect of heavy metals on some proximate composition of Echhornia crassipes. Journal of Applied Sciences \& Environmental Management, 10 (1), 83-87.

Postori, G. M., Kidde, G. and Antoniw, J. (2003) Leaf vitamin $\mathrm{C}$ contents modulate plant defense transcripts and regulate genes that control development through hormone signaling. Plant Cell, 15, 939-951.

Reddy, A.M., Kumar, S.G., Jyothsnakumari, G., Thimmanaik, S. and Sudhakar, C. (2005) Lead induced changes in antioxidant metabolism of 
horsegram (Macrotyloma uniflorum (Lam.) Verdc.) and bangalgram (Cicer arietinum L.). Chemosphere, 60, 97-104.

Rossato, L.V., Nicoloso, F.T., Farias, J.G., Cargnelluti, D., Tabaldi, L. A., Antes, F. G., Dressler, V. L., Morsch, V. M. and Schetinger, M. R. C. (2012) Effects of lead on the growth, lead accumulation and physiological responses of Pluchea sagittalis. Ecotoxicology, 21, 111-123.

Sadak, M.Sh. and Dawood, M.G. (2014) Role of ascorbic acid and $\alpha$ tocopherol in alleviating salinity stress on flax plant (Linumu sitatissimum L.). J. Stress Physiology and Biochem. 10, 93-111.

Schat, H., Sharma S. S and Vooijs, R. (1997) Heavy metal-induced accumulation of free proline in a metal-tolerant and a non-tolerant ecotype of Silene vulgaris. PhysiologiaPlantarum, 101, 477-482.

Seregin, I.V. and Kosevnikova, A.D. (2008) Roles of root and shoot tissues in transport and accumulation of cadmium, lead, nickel, and strontium. Russ. J. Plant Physiol. 55,1-22.

Sharma, P. and Dubey, R. S. (2005) Lead toxicity in plants. Braz. J. Plant Physiol. 17, 35-52.

Sharma, S. S. and Dietz, K. (2005) The significance of amino acids and amino acid-derived molecules in plant responses and adaptation to heavy metal stress. Society for Experimental Biology, 57(4),711- 726.

Sharma, P., Jha, A. B., Dubey, R. S. and Pessarakli, M. (2012) Reactive oxygen species, oxidative damage, and antioxidative defense mechanism in plants under stressful conditions. Journal of Botany, Volume 2012, Article ID 217037, 26 pages.

Singh, R., Tripathi, R. D., Dwivedi, S., Kumar, A.,Trivedi, P. K. and Chakrabarty, D. (2010) Lead bioaccumulation potential of an aquatic macrophyte Najas indica are related to antioxidant system. Bioresour Technol. 101, 3025-3032.

Smirnoff, N. (2000) Ascorbic acid: metabolism and functions of a multi-facetted molecule. Current Opinion in Plant Biol. 3, 229-235.
Symonowicz, M. and Kolanek, M. (2012) Flavonoids and their properties to form chelate complexes Biotechnol Food Sci. 76 (1), 35-41.

Tahara, S. (2007) A journey of twenty-five years through the ecological biochemistry of flavonoids. Bioscience, Biotechnology and Biochemistry,71, 1387-1404.

Tarraf, S. A., El-Din, K. G. and Balbaa, L. K.( 1999) The response of vegetative growth, essential oil of lemongrass to foliar application of ascorbic acid, nicotinamid and some micronutrients. Arab Univ. J. of Agric. Sci. 7, 247-259.

Tripathi, B. N., and Gaur, J. P. (2004) Relationship between copper and zinc-induced oxidative stress and proline accumulation in Scenedesmus $s p$. Planta, 219, 397-404.

Wang, C., Tian, Y., Wang, X., Geng, J., Jiang, J., Yu, H. and Wang, C. (2010) Lead-contaminated soil induced oxidative stress, defense response and its indicative biomarkers in roots of Vicia faba seedlings. Ecotoxicology, 19, 1130-1139

Yordanov, I. and Merakchiiska, T. (1976) The effect of lead on photosynthetic rate, $\mathrm{C} 14$ distribution, chloroplast protein composition, and PS I and PS II spectral properties. Fiziologiya Rastenii, 2, 3-9.

Younis, M. E., Below, F. E. and Hesketh, J. D. (1987) Plant growth, metabolism and adaptation in relation to stress conditions. IV. Effect of salinity on certain factors associated with the germination of three seeds high in fats. Journal Annual of Botany, 60, 334-337.

Zhang, Y. (2012) "Ascorbic Acid in Plants: Biosynthesis, Regulation and Enhancement." Dordrecht, SpringerBriefs in Plant Science.

Zheljazkov, V.D., Craker, L. E. and Xing, B. (2006) Effects of $\mathrm{Cd}, \mathrm{Pb}$ and $\mathrm{Cu}$ on growth and essential oil contents in dill, peppermint and basil. Environ. Exp. Bot. 58, 9-16.

Zhou, Y., Huang, S., Yu, S., Gu, J., Zhao, J., Han, Y. and Fu, J. (2010) The physiological response and sub-cellular localization of lead and cadmium in Iris pseudacorus

Received: 8/2/2017

Accepted: 16/3/2017 


\title{
دراسات فسيولوجية علي التأثيرات المتاخلة للرصاص ومضادات الأكسدة لنبات الكراوية \\ رفعت محمد علي ، محمود حافظ محمود ، هثام محمد عباس و مروة فخر قسم النبات - كلية العلوم - جامعة الفيوم - الفيوم - مصر.
}

\begin{abstract}
أجريت تجربة لتحديد استجابات نبات الكر اوية لإجهاد الرصاص ، و استخدام حمض الاسكوربيك و الفاتوكوفيرول كمضادات

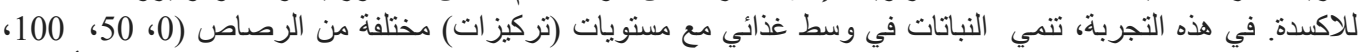

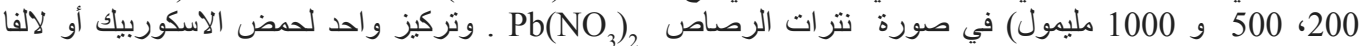

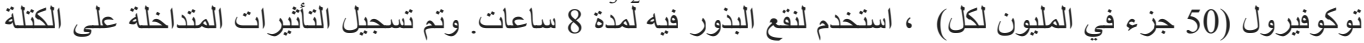

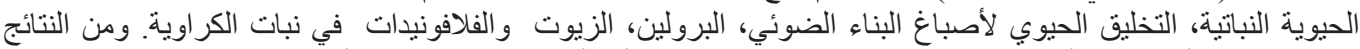

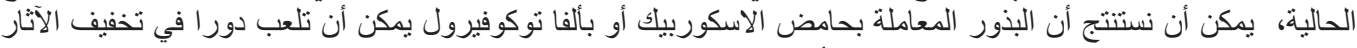

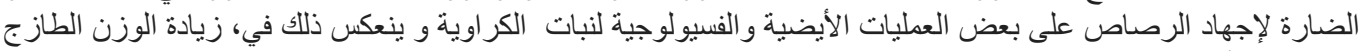

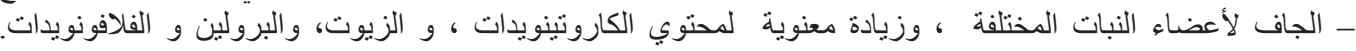


دراسات فسيولوجية علي التأثثرات المتداخلة للرصاص ومضادات الأكسدة لنبات الكراوية.

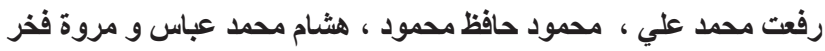

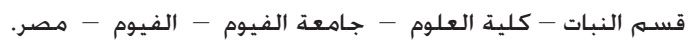

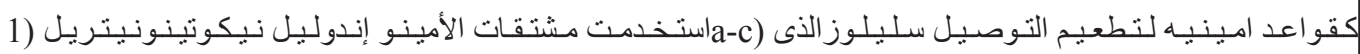

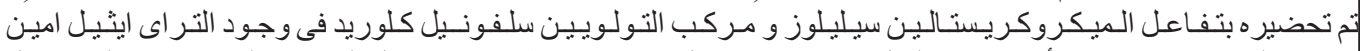

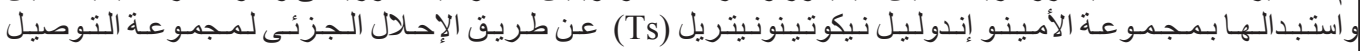

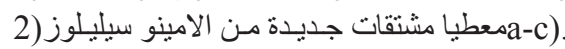

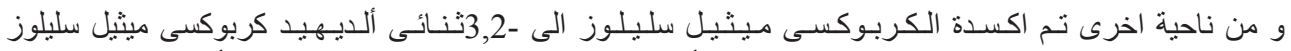

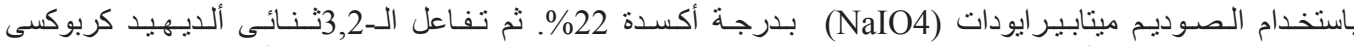

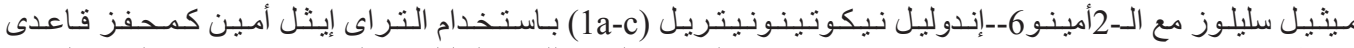

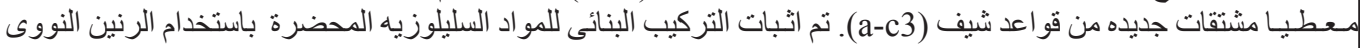
المغناطيسى , الاشعه تحت الحمراء, المسح الاكترونى الميكروسكوبى, و الاشعة السينيه.

اختبرت فاعلية المشتقات السليلوزيه المحضره (a-c2) و (a-c3) كمضادات لنمو البكتريـا. مشتقات الامينو

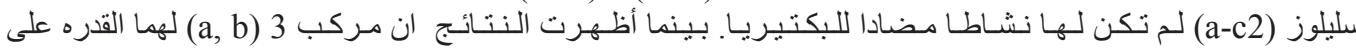

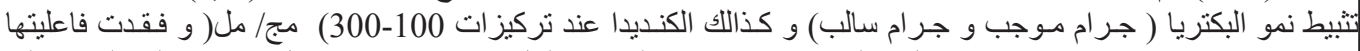

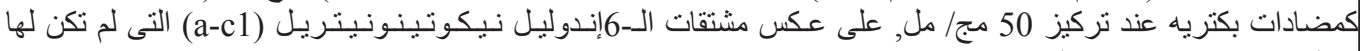

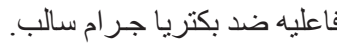

